\title{
A flexible method for the stable, covalent immobilization of enzymes at electrode surfaces
}

\author{
Firas A. Al-Lolage, ${ }^{[a, b]}$ Marta Meneghello, ${ }^{[a]}$ Su Ma, ${ }^{[c]}$ Roland Ludwig,${ }^{[c]}$ and Philip N. Bartlett ${ }^{\star[a]}$
}

\begin{abstract}
Stable, site-specific immobilization of redox proteins and enzymes is of interest for the development of biosensors and biofuel cells, where the long-term stability of enzymatic electrodes as well as the possibility of controlling the orientation of the biomolecules at the electrode surface have a great importance. Ideally, it would be desirable to immobilise redox proteins and enzymes in a specific orientation, but still with some flexibility to optimise reaction kinetics. In this work, we establish such an approach using site-directed mutagenesis to introduce cysteine residues at specific locations on the protein surface and the reaction between the free thiol group and maleimide groups attached to the electrode surface to immobilise the mutated enzymes. Using cellobiose dehydrogenase $(\mathrm{CDH})$ as a model system, carbon nanotubes electrodes were first covalently modified with maleimide groups following a modular approach based on electrografting of primary amines at the carbon surface and solid phase synthesis methodology to elaborate the surface modified electrode. The $\mathrm{CDH}$-modified electrodes were tested for direct electron transfer (DET), showing high catalytic currents as well as excellent long-term storage stability. The key advantage of this method is its great flexibility, as the main components of the modification can be independently varied to change the local environment at the electrode surface and a wide range of redox proteins or enzymes can be specifically engineered to present cysteine residues at their surface for oriented immobilisation.
\end{abstract}

\section{Introduction}

The immobilization of enzymes at electrode surfaces is fundamental for biosensing and biofuel cell applications, where redox enzymes are used as recognition molecules or catalysts. The use of enzymes in such applications offers advantages, such as extraordinary selectivity toward the reactants, high activity and stability at moderate $\mathrm{pH}$ and temperature. ${ }^{[1]}$ Moreover, devices that use enzymes can be completely biocompatible and biodegradable, so that they could serve as

[a] F. A. Al-Lolage, M. Meneghello, Prof. P. N. Bartlett Chemistry, Faculty of Natural and Environmental Sciences University of Southampton Southampton SO17 1BJ, UK E-mail: P.N.Bartlett@soton.ac.uk

[b] F. A. Al-Lolage

Department of Chemistry, Faculty of Science University of Mosul

Mosul, Iraq

[c] Dr. S. Ma, Dr. R. Ludwig Department of Food Science and Technology, BOKU University of Natural Resources and Life Sciences Muthgasse 18, Vienna A-1190, Austria

Supporting information for this article is given via a link at the end of the document. implantable medical devices or as environmental, self-powered sensors. ${ }^{[2]}$ However, the realisation of these desirable characteristics is often hampered by poor shelf-storage life and lack of long-term operational stability. ${ }^{[3]}$ In addition, efficient direct electron transfer between the electrode and the redox enzyme is not always achieved, even when theoretically possible, making necessary the use of redox mediators. ${ }^{[4]}$ Using a mediator adds an extra step to the electron transfer chain, usually introducing interferences in a biosensor or lowering the catalytic rate and decreasing the voltage in a biofuel cell. Moreover, mediators may not be biocompatible, preventing the use of biosensors and biofuel cells for applications such as implantable medical devices.

What is the best way to immobilise enzymes at electrode surfaces? There is not a generally agreed answer to this question. However, we can try to specify some attractive features of the ideal immobilisation. First, we should be able to control the orientation of the enzyme at the electrode surface to optimise direct electron transfer without using diffusing redox mediators. Second, the immobilised enzyme should be strongly bound and maintain its activity. Third, the method should be generally applicable, working for a range of enzymes and electrode types. Fourth, the immobilization procedure should be easy to carry out. Finally optimal immobilisation of the enzyme can improve the stability ${ }^{[5]}$. In this work, we present the results of our recent attempts to meet this challenge.

A wide range of methods to immobilise enzymes at electrodes have been described in the literature ${ }^{[6]}$. They range from the use of reversible physical adsorption and ionic linkages to stable covalent bonds. ${ }^{[3,7]}$ However, in many case they do not allow control over the orientation of the enzyme at the electrode surface. To address this problem of orientation several selective immobilization methods able to proceed under mild physiological conditions have received increasing attention. ${ }^{[8]}$ Some of these methods rely on the labelling of proteins with an azide moiety, which can then react with alkynes (Huisgen 1, 3-dipolar cycloaddition or "click chemistry"[9]) or be activated with a phosphine to react with a variety of electrophiles (Staudinger ligation $\left.{ }^{[10]}\right)$. For a site-selective attachment, this method also requires the use of an enzymatic site-selective labelling procedure. In addition, activation reagents or catalysts are necessary for quantitative reaction yields. A promising recent example is the use of the thiol-ene click reaction to attach a cysteine tagged enzyme to a vinyl group at the electrode surface using a tris-(2-carboxylethyl) phosphine catalyst. ${ }^{[11]}$ Another sitespecific immobilization method is given by the introduction of genetically encoded affinity tags in the protein structure, such as the well-known polyhistidine tag (His-tag), typically consisting of six sequential histidine residues that can chelate metals such as $\mathrm{Cu}(\mathrm{II}), \mathrm{Co}(\mathrm{II}), \mathrm{Zn}(\mathrm{II})$ or $\mathrm{Ni}(\mathrm{II}) .^{[12]}$ However, the strength of the binding interaction is relatively weak $\left(K_{d} \approx 1-10 \mu \mathrm{M}\right)$ and the 
selectivity of this method is rather low since several proteins have been identified that are also able to bind metal ions, thus competing with the desired histidine tag. In addition, this method is usually used to attach the tag at either the $\mathrm{N}$ - or C-terminus of the polypeptide chain and the His-tag is a bulky group.

In the present paper, we adopt a selective immobilization method that employs the coupling of an amino acid residue, namely cysteine, with unsaturated carbonyls, such as maleimide to form stable thioether bonds (Scheme 1). It has been shown that maleimide groups strongly favour conjugate addition with thiols at physiological pH (6.5-7.5) without the need of any other reagent or catalyst, ${ }^{[13]}$ while under these conditions amines are predominantly protonated and unreactive. ${ }^{[3]}$ Since proteins generally have very few surface-exposed cysteine residues, this method can be highly site-selective if it is combined with sitedirected mutagenesis ${ }^{[14]}$ to engineer the removal of all but one surface cysteine from, or to insert a single cysteine at a chosen location on, the enzyme surface. The absence of the requirement for any added reagent or catalyst for the maleimide thiol coupling reaction and its mild conditions represent a significant advantage making the process very efficient in its use of engineered enzyme. As a model system, we use two genetically engineered cellobiose dehydrogenase $(\mathrm{CDH})$ variants with cysteine at two different locations on the enzyme surface.
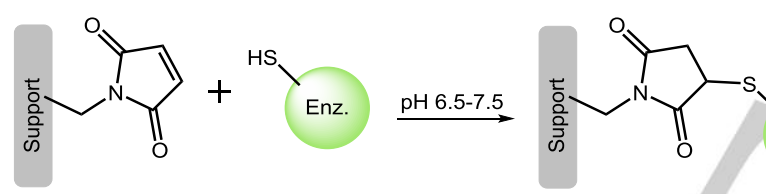

Enz.

Scheme 1. Reaction of a maleimide group immobilised onto a support with the thiol of a cysteine residue.

\section{Results and Discussion}

Glassy carbon electrodes modified with multiwall carbon nanotubes (GC/MWCNT) were chosen as a model for carbonbased electrodes because of their high surface area combined with relatively low capacitance. These were modified with maleimide groups following a method developed in previous work by our group using electrochemical surface attachment and solid phase synthesis methodology. ${ }^{[15]} \mathrm{A}$ key aspect of our procedure is the creation of a modified surface on the electrode in a stepwise manner, allowing the single elements of the construction to be independently varied. In this case these elements are a "linker", a "spacer", a "reactive group" and a "passivating group", Scheme 2. The "linker" provides the attachment between the electrode and the rest of the modification connecting to the enzyme: it has two functionalities that allows it to be electrochemically grafted on the electrode surface and then chemically linked with other molecules. The "spacer" can be introduced after the linker to lengthen the linkage; it has two functional groups, one to react with the linker and the other with the reactive group, and it can be of different length. The "reactive group" is the final component in the linkage; it is chemically attached to the linker or spacer through one of its functionalities and has a second functional group suitable to react with the target group on the desired protein or biomolecule. Finally, the "passivating group" is, normally, a small molecule co-grafted at the electrode surface with the linker to form a two-component monolayer on the electrode in order to dilute the reactive groups and provide a film compatible with the surface of the enzyme around the attachment point, thus to reduce denaturation of the protein.

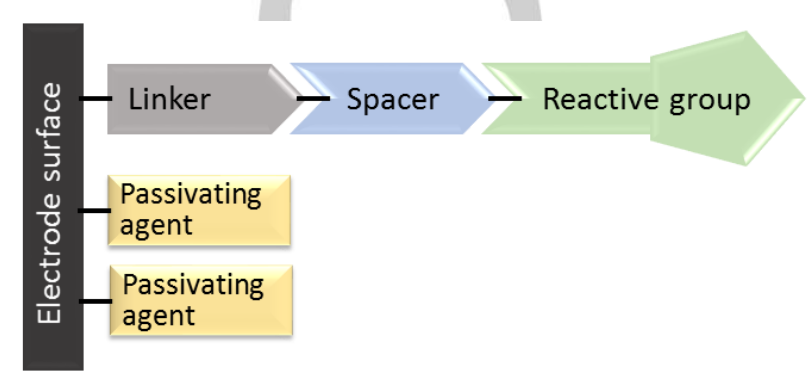

Scheme 2. Schematic representation of the stepwise modified electrode, with key elements highlighted.

A mono-Boc-protected diamine was chosen as the linker due to its efficient electrografting to carbon surfaces through electrochemical oxidation ${ }^{[16]}$ to give a stable attachment. This represents a versatile, modular method for electrode modification since, after removal of the Boc protecting group, a wide range of molecules can be coupled to the amino-modified surface using conventional solid-phase synthesis methodology ${ }^{[17]}$ to build up the desired molecular architecture on the electrode and to tune the electrode properties. ${ }^{[18]} \mathrm{A}$ significant aspect of the design is the dilution of the reactive group, maleimide in our case, at the surface and the length of the linkage. Redox enzymes are large, three-dimensional objects with non-uniform surfaces. Dilution of the reactive group on the surface of the electrode and the choice of a suitable length of linkage allows the maleimide to react with the cysteine at the enzyme surface without steric restrictions. ${ }^{[15]}$

Cellobiose dehydrogenase $(\mathrm{CDH})^{[19]}$ was chosen as the model redox enzyme system in this work. $\mathrm{CDH}$ is a fungal extracellular redox enzyme that catalyses the oxidation of carbohydrates. It is a monomeric protein, between 85 and $101 \mathrm{kDa}$ in mass depending on degree of glycosylation, comprising two domains, one containing a flavin and the other a haem redox centre. The two domains are joined by a flexible linker of around 20 amino acids that allows the two to come in close contact for internal electron transfer. ${ }^{[20]}$ When $\mathrm{CDH}$ is immobilised at the electrode surface it can catalyse the oxidation of glucose by reaction of glucose with the oxidised flavin $\left(\mathrm{FAD}^{+}\right)$to give gluconolactone and the fully reduced flavin $\left(\mathrm{FADH}_{2}\right)$. In the absence of added redox mediator, the flavin is reoxidised by intramolecular electron transfer to the haem and from the haem to the electrode in two sequential steps going through the semiquinone radical of the FAD cofactor. ${ }^{[21]}$ 
Current interest in the enzyme derives from its possible application both in biosensors and biofuel cells. ${ }^{[21]}$ The crystal structure of the enzyme is $\mathrm{known}^{[22]}$ and it does not have any surface cysteines making it an ideal candidate for site directed mutagenesis to introduce cysteines at specific surface location for immobilisation. In this study, we used two Myriococcum thermophilum cellobiose dehydrogenase $(M t C D H)$ mutants, E522 and T701, with single cysteine residues on the surface of the flavin domain (Figure 1).

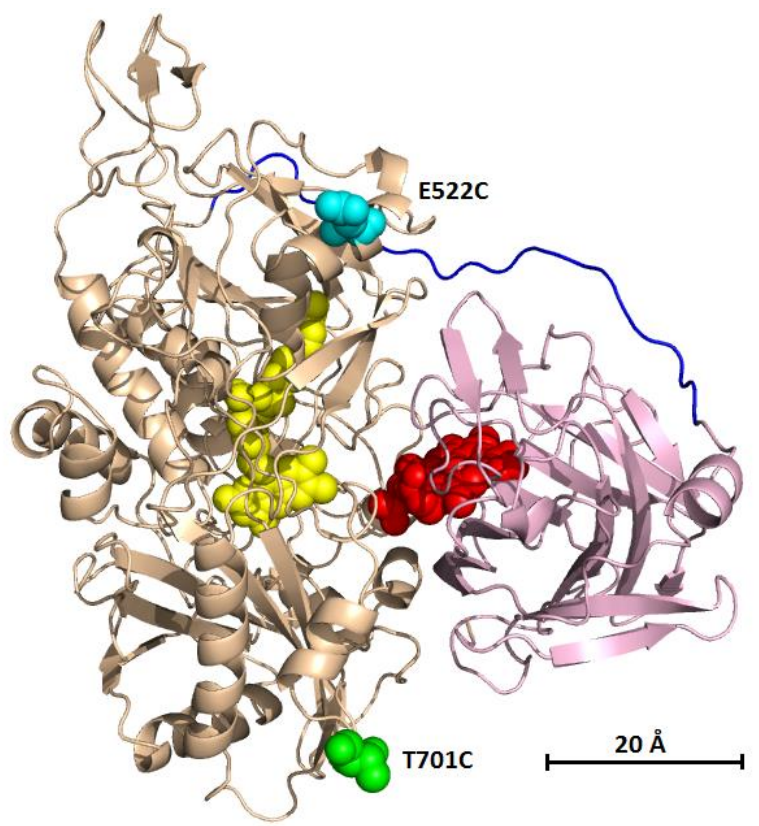

Figure 1. Cartoon representation of secondary structure of Myriococcum thermophilum cellobiose dehydrogenase. The sites of the E522 and T701 mutations are highlighted in blue and green, respectively; the flavin domain with the FAD group in beige/yellow and cytochrome domain with the haem group in pink/red. The amino acids chain linking the two domains is in blue. Note, this is a simplified representation of the location of the two mutations, they are not both present in one enzyme, but in two distinct variants.

The positions for introduction of the cysteine residues were selected to ensure mobility of the cytochrome domain after immobilisation, because the mobility of the cytochrome domain is necessary for direct electron transfer. The cysteine mutation for the variant E522 is on top of the $\mathrm{CDH}$ molecule in Figure 1 and requires the cytochrome domain not only to move away from the dehydrogenase domain, but also to rotate to contact the electrode with its haem cofactor. The other position, T701 requires only a small movement of the cytochrome domain and no reorientation of the haem towards the electrode.

\section{Electrode modification and MtCDH Immobilization}

GC/MWCNT electrodes were modified with a mixture of two primary amines, Scheme 3 , in order to dilute the ultimate number of maleimide groups in the final film. The method for the covalent, site-specific immobilization of cysteine-modified
MtCDH on GC/MWCNT electrodes follows previous work in our group. ${ }^{[15]}$ The linker (N-Boc-1,6-hexanediamine) and the passivating group ( $\mathrm{N}$-(2-aminoethyl)acetamide) were grafted to the GC/MWCNT electrodes through electrochemical oxidation from an acetonitrile solution containing $10 \%$ of the linker and $90 \%$ of the passivating group. The electrode potential was held constant at $+2 \mathrm{~V} v s$. SCE; at this potential both amines are oxidised forming the corresponding amine radicals. If we assume similar reactivity for the two radicals formed, we expect the ratio of their surface coverages to be similar to the ratio of their solution concentrations. After electrografting, the Bocprotecting group was removed and a six carbon-long spacer was added to the 1,6-hexadiamine linker in order to lengthen the linkage, making it more flexible and accessible to the enzyme, Scheme 3. The six carbon-long spacer was introduced by coupling $\mathrm{N}$-Boc-6-aminohexanoic acid onto the amino-modified surface. Overall, this gives a tether approximately $3 \mathrm{~nm}$ long and was chosen to ensure that the maleimide binding group can easily reach the cysteine residue at the $\mathrm{CDH}$ surface. After removal of the Boc protecting group, $N$-maleoyl- $\beta$-alanine was coupled to the amino-modified surface to produce the maleimide-modified electrode.

One of the advantages of maleimide is that it couples spontaneously to free thiols in aqueous solution at neutral $\mathrm{pH}$ allowing very efficient use of small quantities of purified enzyme. Coupling of the MtCDH variants was carried out by drop casting $3 \mu \mathrm{L}$ of $\mathrm{CDH}$ solution (at $\mathrm{pH} 7.0$ ) on the electrode and leaving it overnight at $4{ }^{\circ} \mathrm{C}$

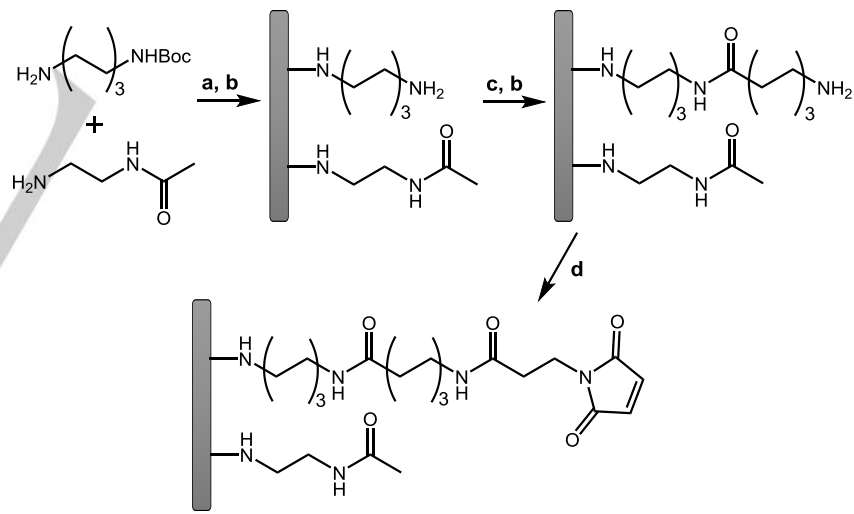

Scheme 3. Sequential electrochemical and solid-phase preparation of maleimide-modified GC/MWCNT electrodes. Reagents and conditions: a) 2 mM N-Boc-1,6-hexanediamine, $18 \mathrm{mM} \mathrm{N}$-(2-aminoethyl)acetamide, $0.1 \mathrm{M}$ TBATFB in deoxygenated acetonitrile, constant potential of $2 \mathrm{~V}$ vs. SCE for $180 \mathrm{~s}$; b) $4 \mathrm{M} \mathrm{HCl}$ in 1,4-dioxane (45 min); c) $10 \mathrm{mM} \mathrm{N}$-Boc-6-aminohexanoic acid, 0.1 M EDC, $60 \mathrm{mM}$ NHS in DMF (16 h); d) $25 \mathrm{mM} \mathrm{N}$-maleoyl- $\beta$-alanine, $0.1 \mathrm{M}$ EDC, $60 \mathrm{mM}$ NHS in DMF (16 h).

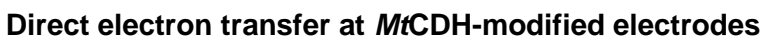

GC/MWCNT electrodes modified with the MtCDH E522 variant (see Figure 1 for the structure) were tested for direct electron transfer (DET) by slow scan cyclic voltammetry in 50 $\mathrm{mM}$ Tris- $\mathrm{HCl}$ buffer, $\mathrm{pH}$ 7.4. Figure 2 shows that, increasing the 
concentration of D-glucose in solution up to $70 \mathrm{mM}$, an increasing catalytic current is visible starting from about $-0.2 \mathrm{~V}$ vs. SCE and reaching a plateau around $-0.05 \mathrm{~V}$.

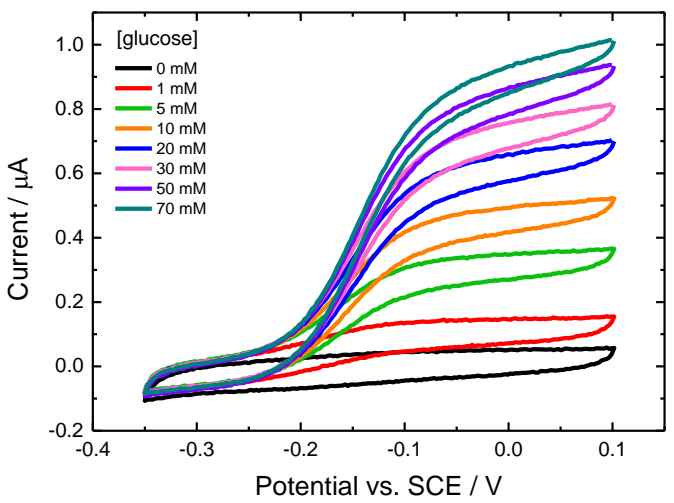

Figure 2. Typical cyclic voltammograms for $\mathrm{CDH}$-modified GC/MWCNT electrode (CDH variant E522) in argon-saturated $50 \mathrm{mM}$ Tris buffer (pH 7.4), containing $30 \mathrm{mM} \mathrm{CaCl} 2$ and increasing concentrations of D-glucose. The electrode potential was swept at $1 \mathrm{mV} / \mathrm{s}$ from -0.35 to $0.1 \mathrm{~V} v$ s. SCE.

The position of the electrocatalytic wave agrees with that reported in the literature for adsorbed $M t C D H$ at silver and graphite electrodes and corresponds to DET from the haem to the electrode. ${ }^{[21,23]}$

Clear evidence that the catalytic current is due to the oxidation of the glucose by the immobilised enzyme is provided by the control experiment using L-glucose, Figure 3, where upon addition of aliquots to increase the concentration of L-glucose in the cell there is no change in the current (compare each pair of dotted and solid curves), whereas upon each addition of an aliquots of D-glucose to increase its concentration in the cell the current increases (compare the solid curves). This chiral selectivity can only be explained by the catalysis of the reaction by the enzyme.

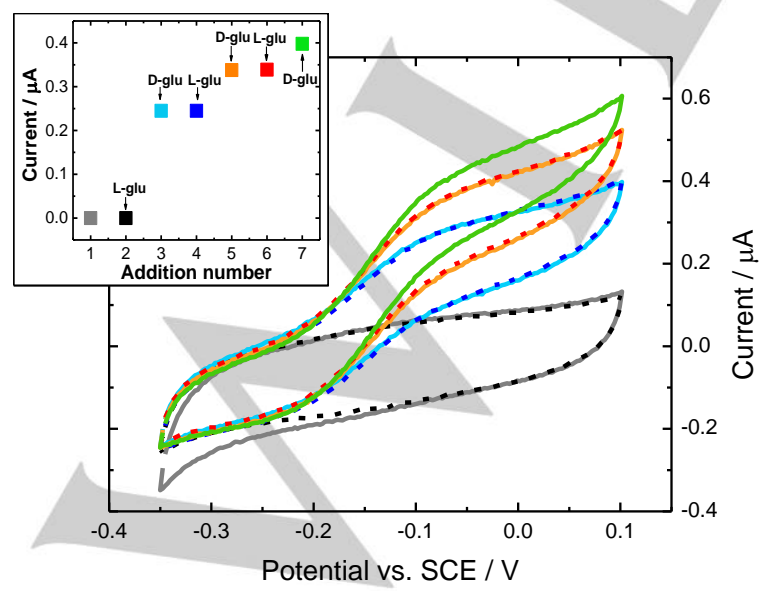

Figure 3. Cyclic voltammograms for a CDH-modified GC/MWCNT electrode (CDH variant E522) in argon-saturated $50 \mathrm{mM}$ Tris buffer ( $\mathrm{pH} 7.4)$, containing $30 \mathrm{mM} \mathrm{CaCl} 2$ (grey line) and increasing concentrations of L- and D-glucose. Solution compositions - Grey: background; Black: $5 \mathrm{mM} \mathrm{L-glu;} \mathrm{Light} \mathrm{Blue:} 5$ $\mathrm{mM} \mathrm{L-glu} \mathrm{and} 5 \mathrm{mM} \mathrm{D-glu;} \mathrm{Blue:} 10 \mathrm{mM} \mathrm{L-glu} \mathrm{and} 5 \mathrm{mM} \mathrm{D-glu;} \mathrm{Orange:} 10$ $\mathrm{mM}$ L-glu and $10 \mathrm{mM}$ D-glu; Red: $15 \mathrm{mM} \mathrm{L-glu} \mathrm{and} 10 \mathrm{mM}$ D-glu; Green: 15 $\mathrm{mM} \mathrm{L-glu} \mathrm{and} 20 \mathrm{mM}$ D-glu. The electrode potential was swept at $1 \mathrm{mV} / \mathrm{s}$. Inset: plot of the background subtracted currents measured at $0.0 \mathrm{~V}$ for all the additions.

\section{Covalent immobilization vs. physical adsorption}

To verify that $\mathrm{CDH}$ was immobilized at the electrode surface through covalent bonding to the surface cysteine, we carried out a comparison using two different $M t C D H$ variants covalently bound and physically absorbed at GC/MWCNT electrodes. For the covalent immobilization, maleimide-modified electrodes were prepared using the procedure described above, while the physically-modified ones were prepared by simply drop casting 3 $\mu \mathrm{L}$ of the MtCDH solution onto a bare (unmodified) GC/MWCNT electrode. Direct electron transfer was observed for both modification methods in the presence of D-glucose (Figure 4). However, the catalytic currents for physically absorbed $M t C D H$ (Figure 4, green and orange circles) were decidedly lower than the ones for covalent immobilized CDH (Figure 4, blue and red squares): in particular, the current was about $60 \%$ less for the variant E522 and $80 \%$ less for the variant T701. Moreover, we can see that the curves of current vs. glucose concentration are the same for the electrodes physically-modified with the two different $M t C D H$ variants. In contrast, for the two covalentlymodified electrodes the curves are different, as expected if the two enzymes are immobilized with different orientations through the cysteine residues located in different positions on the enzyme surface (see Figure 1). As a final control, a maleimidemodified GC/MWCNT electrode was prepared by reaction with the variant E522 dissolved in a pH 5.5 buffer $(50 \mathrm{mM}$ sodium acetate) instead of the normal $\mathrm{pH} 7$ buffer (50 mM phosphate) used in the immobilization procedure. The results of this electrode (Figure 4, black squares) are comparable with the ones of the physically-modified electrodes, indicating that at $\mathrm{pH}$ 5.5 covalent attachment has not occurred. This is consistent with the fact that the coupling reaction between cysteine and maleimide occurs at neutral $\mathrm{pH}(6.5-7.5)$ while at acidic $\mathrm{pH}$ the thiol group is not nucleophilic enough to react with maleimide ${ }^{[13}$ ${ }^{24]}$ ( $\mathrm{pK}$ of the cysteine side chain in folded proteins is around 6.8). ${ }^{[25]}$ 


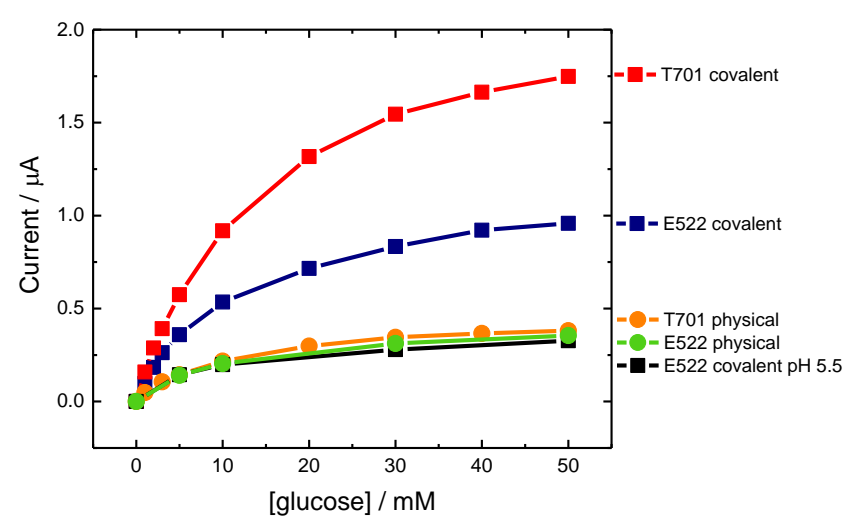

Figure 4. Background subtracted currents measured at $0.0 \mathrm{~V}$ vs. SCE in cyclic voltammograms recorded at maleimide-modified electrodes (squares) and unmodified GC/MWCNT electrodes (circles) with the two different CDH variants $\mathrm{E} 522$ and T701. The $\mathrm{CDH}$ immobilization was made at $\mathrm{pH} 7$ for all the electrodes, except for one (black squares) where variant E522 was drop cast from a $\mathrm{pH} 5.5$ solution. CVs were carried out in argon-saturated $50 \mathrm{mM}$ Tris buffer $(\mathrm{pH} 7.4)$, containing $30 \mathrm{mM} \mathrm{CaCl}_{2}$ and increasing concentrations of Dglucose, sweeping the potential at $1 \mathrm{mV} / \mathrm{s}$ from -0.35 to $0.1 \mathrm{~V} v \mathrm{~s}$. SCE.

The results in Figure 4 are consistent with covalent binding of $\mathrm{CDH}$ at the maleimide-modified electrodes. The higher catalytic currents obtained with covalently-modified electrodes can be explained by immobilization of a greater quantity of enzyme molecules at the surface and/or the fact that the covalently immobilized enzyme is held in a more suitable orientation for DET as compared to the randomly orientated physically absorbed $\mathrm{CDH}$. The differences between the covalently immobilized variants E522 and T701 reflect differences in the enzyme kinetics for different enzyme immobilization orientations. For the variant E522, the position of attachment is on the top of the $\mathrm{CDH}$ molecule (Figure 1) and requires the cytochrome domain not only to move away from the dehydrogenase domain, but also to rotate to contact the electrode with its haem cofactor. In contrast for the T701 variant only a small movement of the cytochrome domain, and no reorientation of the haem towards the electrode, is required. This difference is consistent with the observed higher currents for the T701 variant. As a final test to verify that $\mathrm{CDH}$ is covalently bound and not physically adsorbed, we incubated the electrodes in citrate buffer solution at pH 3.5 and periodically tested the response to glucose. Changing the $\mathrm{pH}$ to 3.5 leads to protonation of the carboxylic acid groups on the MWCNTs $\left(p K_{a} \sim 4.5\right)^{[26]}$ and CDH $(p / \sim 3.8)^{[21]}$ which should significantly alter the strength of the physical adsorption of the $\mathrm{CDH}$. In this experiment the activity of the electrode with physically adsorbed enzyme drops to $8 \%$ in $6 \mathrm{~h}$ whereas that for the enzyme variant immobilised through maleimide remained at $84 \%$ over the same period (see Figure S4).

\section{Stability of the CDH-modified electrodes}

The CDH-modified GC/MWCNT electrodes were found to be very stable for long periods showing the same activity after two months (about $40 \%$ of the initial activity) as after one week from the preparation, Figure 5 . Note that the enzyme immobilised at the maleimide electrode is much more stable than the control for the adsorbed variant E522 at an unmodified GC/MWCNT electrode, where the catalytic response decays much more rapidly. After the initial decrease in activity, the covalently modified electrode maintained roughly the same activity for a period of at least two months when stored at $4{ }^{\circ} \mathrm{C}$ wet with the same buffer used for the tests $\left(50 \mathrm{mM}\right.$ Tris $/ 30 \mathrm{mM} \mathrm{CaCl}_{2}, \mathrm{pH}$ 7.4). The small fluctuations in the activity observed during the test are probably due to experimental factors, such as slightly different temperature or concentration of glucose.

The significant initial decrease in activity during the first week for the maleimide immobilised enzyme can be accounted for by desorption of physically absorbed $\mathrm{CDH}$ as well as the possible loss of the haem group from bound enzyme, which would make some CDH molecules unable to undergo DET. Note, we do not attribute the decrease in response to loss of MWCNTs from the GC electrode surface as separate experiments (see Supplementary Information) show no change in the capacitive background currents for the electrodes over the same period.

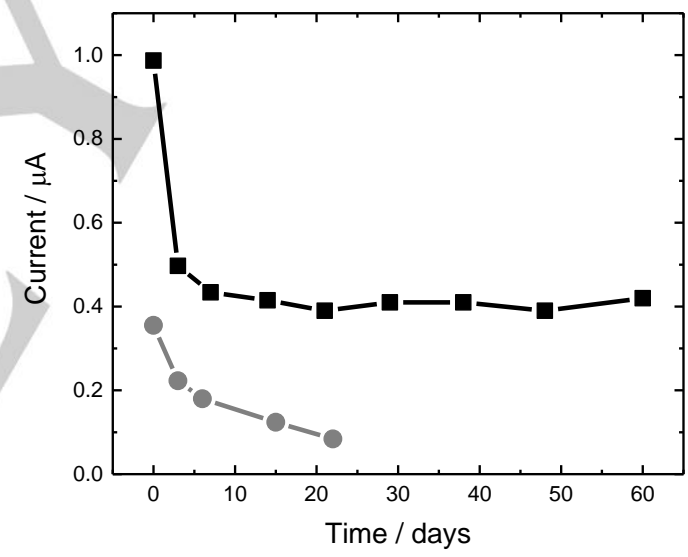

Figure 5. Background subtracted currents measured at $0.1 \mathrm{~V}$ vs. SCE in cyclic voltammograms recorded at $\mathrm{CDH}$-modified GC/MWCNT electrodes (CDH variant E522 in argon-saturated $50 \mathrm{mM}$ Tris buffer $(\mathrm{pH} 7.4)$, containing $30 \mathrm{mM}$ $\mathrm{CaCl}_{2}$ and $50 \mathrm{mM}$ D-glucose. Black squares: enzyme immobilised through maleimide. Grey circles: control, physically adsorbed enzyme on unmodified $\mathrm{GC} / \mathrm{MWCNT}$. The electrodes were stored in wet condition at $4{ }^{\circ} \mathrm{C}$ for two months.

\section{Conclusions}

In this paper we have presented a flexible and structured approach to the oriented immobilization of redox proteins and enzymes at electrode surfaces based on the use of site directed mutagenesis to introduce cysteine residues at specific locations on the enzyme surface and reaction between the free thiol and a maleimide group on the electrode surface. Using electrografting of mixed solutions of primary amines we are able to form mixed 
monolayers at carbon electrode surfaces where the majority component is a passivating group, in the present case $\mathrm{N}-(2-$ aminoethyl) acetamide, and the minority component is a monoBoc protected diamine, in this case $\mathrm{N}$-Boc-1,6-hexanediamine. Subsequent removal of the Boc protecting group and coupling to the resulting free amine at the surface, using solid state synthesis methodology, then allows a spacer to be added, in the present case 6-aminohexanoic acid, followed by the reactive group, maleimide. In this way, the modular construction of the surface modifying layer allows independent control over the local environment around the enzyme attachment site through choice of the passivating group, the length and chemistry of the linking chain, and orientation of the enzyme through choice of the mutation site. The maleimide/thiol coupling reaction is attractive in this context because it occurs spontaneously in aqueous solution at neutral $\mathrm{pH}$, therefore ensuring efficient use of the genetically engineered enzyme.

Using two variants of Myriococcum thermophilum cellobiose dehydrogenase we have shown that this approach leads to stable attachment of the enzyme to the electrode surface and that the immobilised enzyme is active for the electrochemical oxidation of D-glucose without added redox mediators. Comparison of the two different $\mathrm{MtCDH}$ variants shows that the position of the mutation on the enzyme surface affects the measured catalytic currents.

\section{Experimental Section}

General: The chemicals used for the covalent modification of electrodes: $\mathrm{N}$-Boc-1,6-hexanediamine, $\mathrm{N}$-(2-aminoethyl)acetamide, tetrabutylammonium tetrafluoroborate (TBATFB), $\mathrm{N}$-hydroxysuccinimide (NHS), $\quad N$-(3-dimethylaminopropyl)- $N$-ethylcarbodiimide (EDC) were purchased from Sigma-Aldrich. $\mathrm{N}$-Boc-6-aminohexanoic acid and $\mathrm{N}$ maleoyl- $\beta$-alanine were synthesised as described below in collaboration with Dr Marloes Peeters at the Queen Mary University, London. Buffer solutions were prepared with Tris base and sodium phosphate monobasic (Sigma-Aldrich), calcium chloride (Fisher Scientific) and titrated with hydrochloric acid $(37 \%, \mathrm{BDH})$ and sodium hydroxide (laboratory grade, Fisher Chemical). D- and L-glucose were purchased from $\mathrm{BDH}$. The solvents acetonitrile (HPLC grade), 1,4-dioxane (laboratory grade) and dimethylformamide (DMF, laboratory grade) were purchased from Fisher Chemical.

Myriococcum thermophilum cellobiose dehydrogenase variants (MtCDH) were recombinantly expressed in Pichia pastoris. The plasmid $\mathrm{pMt} 1^{[27]}$ was used as template for the amplification of Myriococcum thermophilum cellobiose dehydrogenase cDNA. Variants of $M$. thermophilum $\mathrm{CDH}$ harbouring the single mutation $\mathrm{E} 522 \mathrm{C}$ or $\mathrm{T701C}$, were introduced using PCR with the primes (E522CFw1: GAGGACCAATTGTGTGTCGTTGCCGCTTCTGAGAAGG; E522Rv1: CAATTGGTCCTCTGGTCCA; T701CFw1: GTTCCCAAACTCTTGTATTACCCCACGTGAGTATGTCG; T701Rv1: AGAGTTTGGGAACAACCAGGTC). Linearized plasmids were transformed into electro-competent Pichia pastoris X-33 cells and transformants were selected on YPD zeocin plates $\left(1 \mathrm{mg} \mathrm{L}^{-1}\right)$. The best $P$. pastoris clones were screened by deep-well-plate microfermentation according to Sygmund et al. ${ }^{[28]}$ Production of the $\mathrm{CDH}$ variants was performed in a Sixfors bioreactor (Infors HT, Bottmingen, Switzerland) similar as previously described. ${ }^{[29]}$ The $\mathrm{CDH}$ variants were purified by hydrophobic interaction chromatography and anion exchange chromatography according to a published procedure to homogeneity. ${ }^{[30]}$ The $\mathrm{CDH}$ variants were stored in $50 \mathrm{mM}$ sodium acetate buffer $(\mathrm{pH}$ 5.5) at $-30^{\circ} \mathrm{C}$.

All electrochemical solutions were prepared with reagent grade water (18 $\mathrm{M} \Omega \mathrm{cm}$ ) from a Purite purification system. Pureshield argon (BOC) was used to purge electrochemical solutions as stated. Electrochemical measurements were performed in glass cells using a standard threeelectrode arrangement, with either a $\mu$ Autolab type III or an Autolab PGSTAT 302 (Ecochemie, Netherlands). A platinum gauze was used as a counter electrode and a home-made saturated calomel electrode (SCE) as the reference. Glassy carbon (GC) working electrodes $(0.071$ $\mathrm{cm}^{2}$ ) were fabricated from $3 \mathrm{~mm}$ diameter glassy carbon rod (HTW Hochtemperatur - Werkstoffe GMBH, Germany) sealed in glass and contacted by copper wire using melted indium (Aldrich). Prior to modification, the electrodes were polished by using silicon carbide polishing paper (grade 1200), then alumina slurries (1.0 and $0.3 \mu \mathrm{m}$, Buehler) on polishing cloths (Buehler), followed by sonication for $5 \mathrm{~min}$ in deionised water and ethanol. GC electrodes were modified using a 1 $\mathrm{mg} / \mathrm{mL}$ DMF dispersion of multi-walled carbon nanotubes (MWCNT, > $8 \%$ carboxylic acid functionalised avg., $9.5 \mathrm{~nm}$ diameter, $1.5 \mu \mathrm{m}$ length, Sigma-Aldrich). $5 \mu \mathrm{L}$ of the MWCNT dispersion were placed onto the clean surface of each $\mathrm{GC}$ electrode using a plastic mask of the same dimension as the GC disc to control the spread of the CNT dispersion, and allowed to dry at room temperature for 2 days. $5 \mu \mathrm{L}$ of the dispersion was used as this gives a reasonably uniform MWCNT coverage (see Supplementary Information).

Boc-protection of 6-aminohexanoic acid (6C-spacer): 6aminohexanoic acid (500 mg, $3.8 \mathrm{mmol}, 1$ eq.) was dissolved in a solution of $1.5 \mathrm{~mL}$ of water, $1.5 \mathrm{~mL}$ of methanol and $1 \mathrm{~mL}$ of triethylamine (TEA, $7.2 \mathrm{mmol}, 1.9$ eq.). Di-tert-butyl dicarbonate $(1.362 \mathrm{~g} 6.2 \mathrm{mmol}, 1.6$ eq.) dissolved in methanol was added slowly. The solution was stirred at $55{ }^{\circ} \mathrm{C}$ overnight. The methanol was removed at the Rotavapor and two consecutive extractions in water/ethyl acetate (50:50) were performed: the first at neutral $\mathrm{pH}$, the second by acidifying the solution with $\mathrm{HCl}$. The organic phase was dried with magnesium sulphate, filtered on paper and the solvent was removed at the Rotavapor and under vacuum pump. ${ }^{1} \mathrm{H}$ NMR (400 MHz, chloroform-d), $\delta$ ppm $1.49(15 \mathrm{H}, \mathrm{m}), 2.38(2 \mathrm{H}, \mathrm{t}, \mathrm{J}=8$ $\mathrm{Hz}), 3.13(2 \mathrm{H}, \mathrm{m}$, broad), $4.56(1 \mathrm{H}, \mathrm{s}$, broad).

Synthesis of $N$-maleoyl- $\beta$-alanine: Maleic anhydride $(4.97 \mathrm{~g}, 51 \mathrm{mmol}$, 1 eq.) and $\beta$-alanine $(4.59 \mathrm{~g}, 51 \mathrm{mmol}, 1$ eq.) were dissolved in acetic acid $(37 \mathrm{~mL})$. The solution was stirred and heated to reflux for $90 \mathrm{~min}$. Then toluene was added to lower the boiling point and the solvent was removed at the Rotavapor (50 mbar). An extraction in water/ethyl acetate (50:50) was performed, the organic phase was desiccated with magnesium sulphate and filtered on paper. After removing the solvent on the Rotavapor and under vacuum pump, the product was recrystallized in ethyl acetate and left in the freezer overnight, then filtered on Buchner, washed with ethyl acetate and dried under vacuum pump. ${ }^{1} \mathrm{H}$ NMR (400 $\mathrm{MHz}$, chloroform-d), $\delta \mathrm{ppm} 2.74(2 \mathrm{H}, \mathrm{t}, \mathrm{J}=8 \mathrm{~Hz}), 3.87(2 \mathrm{H}, \mathrm{t}, \mathrm{J}=8 \mathrm{~Hz})$, $6.74(2 \mathrm{H}, \mathrm{s}), 9.94(1 \mathrm{H}, \mathrm{s}$, broad).

\section{Procedure for the modification of GC/MWCNT electrodes: A solution} containing $\quad \mathrm{N}$-Boc-1,6-hexanediamine $(2 \mathrm{mM}), \quad \mathrm{N}$-(2aminoethyl)acetamide $(18 \mathrm{mM})$ and TBATFB $(0.1 \mathrm{M})$ in acetonitrile was prepared and sparged with argon $(20 \mathrm{~min})$ in the electrochemical cell. The covalent immobilization of the amines onto GC/MWCNT electrodes was performed by chronoamperometry holding the electrode potential at $+2 \mathrm{~V} v$ s. SCE for $180 \mathrm{~s}$. The electrode was then washed with acetonitrile and the Boc-protecting group was removed in $4 \mathrm{M} \mathrm{HCl}$ in dioxane (45 $\mathrm{min})$ under gently stirring. For the coupling of $6 \mathrm{C}$-spacer, a solution containing N-Boc-6-aminohexanoic acid (10 mM), NHS $(60 \mathrm{mM})$ and EDC $(0.1 \mathrm{M})$ in DMF was prepared and stirred for $15 \mathrm{~min}$. Electrodes were immersed for $16 \mathrm{~h}$, then washed with acetonitrile and water and dried. The Boc-protecting group was removed from the $6 \mathrm{C}$-spacer in $4 \mathrm{M}$ 
$\mathrm{HCl}$ in dioxane (45 min) under gently stirring. For the coupling of maleimide, a solution containing $N$-maleoyl- $\beta$-alanine $(25 \mathrm{mM}), \mathrm{NHS}$ (60 $\mathrm{mM})$ and EDC (0.1 M) in DMF was prepared and stirred for $15 \mathrm{~min}$. Electrodes were immersed for $16 \mathrm{~h}$, then washed with acetonitrile and water and dried.

Immobilization of $\mathbf{M t C D H}$ variants: The storage buffer of the enzyme was exchanged from $\mathrm{pH} 5.5$ acetate $(50 \mathrm{mM})$ to a $\mathrm{pH} 7.0$ phosphate buffer $(50 \mathrm{mM})$ using mini dialysis devices provided with a PES membrane (Fisher Scientific) with $10 \mathrm{kDa}$ cut off. After dialysis, $3 \mu \mathrm{L}$ of the $\mathrm{CDH}$ variant of choice was placed on each maleimide-modified electrode, which was then stored in the fridge $\left(4^{\circ} \mathrm{C}\right)$ overnight.

Analysis of CDH-modified GC/MWCNT electrodes: Cyclic voltammetry measurements of $\mathrm{CDH}$-modified electrodes were carried out in $50 \mathrm{mM}$ Tris buffer $(\mathrm{pH} 7.4)$, containing $30 \mathrm{mM} \mathrm{CaCl}$. All solutions were deoxygenated by bubbling gas argon for 30 min before applying potential, and for a few minutes after every addition of glucose from a $1 \mathrm{M}$ stock solution (in the same buffer used for the measurement). CVs were carried out using the Nova 1.10 software, normally sweeping the potential at $1 \mathrm{mV} / \mathrm{s}$ from -0.35 to $0.1 \mathrm{~V}$ vs. SCE. The data were analysed using Origin 9 software.

\section{Acknowledgements}

The authors would like to thank Prof. Jeremy D. Kilburn (University of Aberdeen, UK) and Dr. Marloes Peeters (Manchester Metropolitan University, UK) for their advice. This work has received funding from the European Union's Seventh Framework Programme for research, technological development and demonstration under grant agreement no. 607793 (BIOENERGY). FAA acknowledges financial support from the Ministry of Higher Education and Scientific Research of Iraq. PNB gratefully acknowledges receipt of a Wolfson Research Merit Award.

Keywords: Enzyme immobilization • Site-specific immobilization - Maleimide $\cdot$ Solid-phase synthesis $•$ Cellobiose dehydrogenase

[1] J. A. Cracknell, K. A. Vincent, F. A. Armstrong, Chem. Rev. 2008, 108, 2439-2461.

[2] a) R. A. Bullen, T. C. Arnot, J. B. Lakeman, F. C. Walsh, Biosens. Bioelectron. 2006, 21, 2015-2045; b) P. Cinquin, Gondran, F. Giroud, S. Mazabrard, A. Pellissier, F. Boucher, J. P. Alcaraz, K. Gorgy, F. S. Cosnier, PLOS ONE 2010, 5, e10476.

[3] A. A. Homaei, R. Sariri, F. Vianello, R. Stevanato, J. Chem. Biol. 2013 $6,185-205$.

[4] a) G. T. R. Palmore, H. H. Kim, J. Electroanal. Chem. 1999, 464, 110 117 ; b) A. E. G. Cass, G. Davis, G. D. Francis, H. A. O. Hill, W. J. Aston, I. J. Higgins, E. V. Plotkin, L. D. L. Scott, A. P. F. Turner, Anal. Chem. 1984, 56
667-671; c) P. Kavanagh, D. Leech, Phys. Chem. Chem. Phys. 2013, 15 4859-4869.

[5] a) U. Guzik, K. Hupert-Kocurek, D. Wojcieszyńska, Molecules 2014, 19 8995-9018; b) R. C. Rodrigues, C. Ortiz, Á. Berenguer-Murcia, R. Torres, R. Fernández-Lafuente, Chem. Soc. Rev. 2013, 42, 6290-6307.

[6] T. Nöll, G. Nöll, Chem. Soc. Rev. 2011, 40, 3564-3576.

[7] a) B. M. Brena, F. Batista-Viera, in Methods in Biotechnology (Ed.: J. M Guisan), Humana Press Inc., Totowa, NJ, 2006, pp. 15-30; b) U. Hanefeld, L. Gardossi, E. Magner, Chem. Soc. Rev. 2009, 38, 453-468; c) N. R. Mohamad N. H. Marzuki, N. A. Buang, F. Huyop, R. A. Wahab, Biotechnol. Biotechnol. Equip. 2015, 29, 205-220.

[8] W. Liu, L. Wang, R. Jiang, Top. Catal. 2012, 55, 1146-1156.

[9] a) J. Kalia, R. T. Raines, ChemBioChem 2006, 7, 1375-1383; b) J. E. Moses, A. D. Moorhouse, Chem. Soc. Rev. 2007, 36, 1249-1262.

[10] a) J. Kalia, N. L. Abbott, R. T. Raines, Bioconjugate Chem. 2007, 18 1064-1069; b) A. Tam, R. T. Raines, Methods Enzymol. 2009, 462, 25-44; c) M. Kohn, R. Breinbauer, Angew. Chem. Int. Ed. 2004, 43, 3106-3116.

[11] L. Zhang, N. Vilà, T. Klein, G.-W. Wieland Kohring, I. Mazurenko, A Walcarius, M. Etienne, ACS Appl. Mater. Interfaces 2016, 8, 17591-17598.

[12] a) L. R. Paborsky, K. E. Dunn, C. S. Gibbs, J. P. Dougherty, Anal. Biochem. 1996, 234, 60-65; b) M. Oshige, K. Yumoto, H. Miyata, S. Takahashi, M. Nakada, K. Ito, M. Tamegai, H. Kawaura, S. Katsura, OJPChem. 2013, 3, 6-10.

[13] A. B. Lowe, Polym. Chem. 2010, 1, 17-36.

[14] a) M. Campas, B. Prieto-Simon, J. L. Marty, Semin. Cell. Dev. Biol. 2009, 20, 3-9; b) K. Hernandez, R. Fernandez-Lafuente, Enzyme Microb. Technol. 2011, 48, 107-122.

[15] E. J. Wright, M. Sosna, S. Bloodworth, J. D. Kilburn, P. N. Bartlett, Chem. Eur. J. 2014, 20, 5550-5554.

[16] a) B. Barbier, J. Pinson, G. Desarmot, M. Sanchez, J. Electrochem Soc. 1990, 137, 1757-1764; b) A. J. Downard, Electroanal. 2000, 12, 1085 1096

[17] a) M. A. Ghanem, J.-M. Chrétien, A. Pinczewska, J. D. Kilburn, P. N. Bartlett, J. Mater. Chem. 2008, 18, 4917-4927; b) M. A. Ghanem , I. Kocak, A. Al-Mayouf, M. Alhoshan, P. N. Bartlett, Electrochim. Acta 2012, 68, 74-80.

[18] a) M. A. Ghanem, J.-M. Chrétien, J. D. Kilburn, P. N. Bartlett, Bioelectrochem. 2009, 76, 115-125; b) A. Pinczewska, M. Sosna, S Bloodworth, J. D. Kilburn, P. N. Bartlett, J. Am. Chem. Soc. 2012, 134 18022-18033.

[19] G. Henriksson, G. Johansson, G. Pettersson, J. Biotechnol. 2000, 78, 93-113.

[20] R. Ludwig, R. Ortiz, C. Schuyz, W. Harreither, C. Sygmund, L. Gorton, Anal. Bioanal. Chem. 2013, 405, 3637-3658.

[21] R. Ludwig, W. Harreither, F. Tasca, L. Gorton, ChemPhysChem 2010 $11,2674-2697$

[22] T.-C. Tan, D. Kracher, R. Gandini, C. Sygmund, R. Kittl, D. Haltrich, B. M. Hällberg, R. Ludwig, C. Divne, Nature Commun. 2015, 6, Art. No. 7542.

[23] P. Kielb, M. Sezer, S. Katz, F. Lopez, C. Schulz, L. Gorton, R. Ludwig U. Wollenberger, I. Zbger, I. M. Weidinger, ChemPhysChem 2015, 16, 1960 1968

[24] J. D. Gregory, J. Am. Chem. Soc 1955, 77 (14), 3922-3923.

[25] G. R. Grimsley, J. M. Scholtz, C. N. Pace, Protein Sci. 2009, 18, $247-$ 251.

[26] A. Flitsch, E. N. Prasetyo, C. Sygmund, R. Ludwig, G. S. Nyanhongo, G M. Guebitz, Enzyme Microb. Technol. 2013, 52, 60-67.

[27] C. Sygmund, P. Santner, I. Krondorfer, C. K. Peterbauer, M. Alcalde, G S. Nyanhongo, G. M. Guebitz, R. Ludwig, Microb Cell Fact 2013, 12.

[28] C. Sygmund, P. Staudigl, M. Klausberger, N. Pinotsis, K. Djinovic Carugo, L. Gorton, D. Haltrich, R. Ludwig, Microb Cell Fact 2011, 10.

[29] W. Harreither, A. K. G. Felice, R. Paukner, L. Gorton, R. Ludwig, C. Sygmund, Biotechnology Journal 2012, 7. 
Entry for the Table of Contents (Please choose one layout)

Layout 1:

\section{FULL PAPER}

Stable, site-specific immobilization of redox proteins and enzymes has a great interest in the development of biosensors and biofuel cells. In this work, we describe a modular approach for the covalent, site-specific immobilization of a redox enzyme, where the key elements of the modification can be independently varied to tune the architecture of the electrode surface as required, by simply changing the "bricks" of the structure.

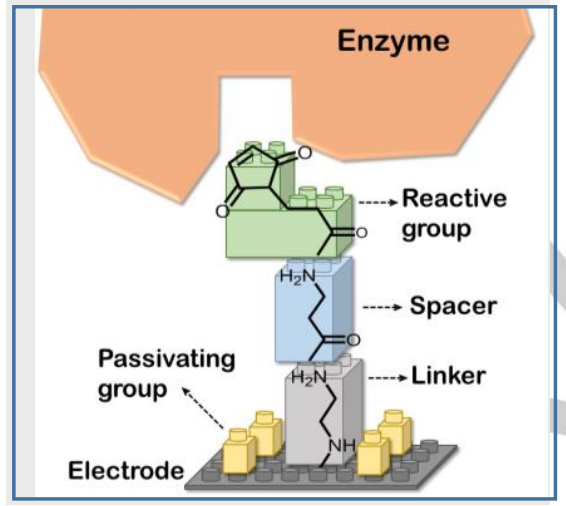

Firas A. Al-Lolage, Marta Meneghello, Su Ma, Roland Ludwig and Philip N. Bartlett*

Page No. - Page No.

A flexible method for the stable, covalent immobilization of enzymes at electrode surfaces

Layout 2:

\section{FULL PAPER}

Page No. - Page No.

Title

Text for Table of Contents

[1] J. A. Cracknell, K. A. Vincent, F. A. Armstrong, Chem. Rev. 2008, 108, 2439-2461.

[2] aR. A. Bullen, T. C. Arnot, J. B. Lakeman, F. C. Walsh, Biosens. Bioelectron. 2006, 21, 20152045; bP. Cinquin, Gondran, F. Giroud, S. Mazabrard, A. Pellissier, F. Boucher, J. P. Alcaraz, K. Gorgy, F. S. Cosnier, PLoS ONE 2010, 5, e10476.

[3] A. A. Homaei, R. Sariri, F. Vianello, R. Stevanato, J. Chem. Biol. 2013, 6, 185-205.

[4] aG. T. R. Palmore, H. H. Kim, J. Electroanal. Chem. 1999, 464, 110-117; bA. E. G. Cass, G. Davis, G. D. Francis, H. A. O. Hill, W. J. Aston, I. J. Higgins, E. V. Plotkin, L. D. L. Scott, A. P. F. Turner, Anal. Chem. 1984, 56, 667-671; cP. Kavanagh, D. Leech, Phys. Chem. Chem. Phys. 2013, 15, 4859-4869. 
[5] aU. Guzik, K. Hupert-Kocurek, D. Wojcieszyńska, Molecules 2014, 19, 8995-9018; bR. C. Rodrigues, C. Ortiz, Á. Berenguer-Murcia, R. Torres, R. Fernández-Lafuente, Chem. Soc. Rev. 2013, 42, 6290-6307.

[6] T. Nöll, G. Nöll, Chem. Soc. Rev. 2011, 40, 3564-3576.

[7] aB. M. Brena, F. Batista-Viera, in Methods in Biotechnology (Ed.: J. M. Guisan), Humana Press Inc., Totowa, NJ, 2006, pp. 15-30; bU. Hanefeld, L. Gardossi, E. Magner, Chem. Soc. Rev. 2009, 38, 453-468; cN. R. Mohamad, N. H. Marzuki, N. A. Buang, F. Huyop, R. A. Wahab, Biotechnol. Biotechnol. Equip. 2015, 29, 205-220.

[8] W. Liu, L. Wang, R. Jiang, Top. Catal. 2012, 55, 1146-1156.

[9] aJ. Kalia, R. T. Raines, ChemBioChem 2006, 7, 1375-1383; bJ. E. Moses, A. D. Moorhouse, Chem. Soc. Rev. 2007, 36, 1249-1262.

[10] aJ. Kalia, N. L. Abbott, R. T. Raines, Bioconjugate Chem. 2007, 18, 1064-1069; bA. Tam, R. T. Raines, Methods Enzymol. 2009, 462, 25-44; cM. Kohn, R. Breinbauer, Angew. Chem. Int. Ed. 2004, 43, 3106-3116.

[11] L. Zhang, N. Vilà, T. Klein, G.-W. Wieland Kohring, I. Mazurenko, A. Walcarius, M. Etienne, ACS Appl. Mater. Interfaces 2016, 8, 17591-17598.

[12] aL. R. Paborsky, K. E. Dunn, C. S. Gibbs, J. P. Dougherty, Anal. Biochem. 1996, 234, 60-65; bM. Oshige, K. Yumoto, H. Miyata, S. Takahashi, M. Nakada, K. Ito, M. Tamegai, H. Kawaura, S. Katsura, OJPChem. 2013, 3, 6-10.

[13] A. B. Lowe, Polym. Chem. 2010, 1, 17-36.

[14] aM. Campas, B. Prieto-Simon, J. L. Marty, Semin. Cell. Dev. Biol. 2009, 20, 3-9; bK. Hernandez, R. Fernandez-Lafuente, Enzyme Microb. Technol. 2011, 48, 107-122.

[15] E. J. Wright, M. Sosna, S. Bloodworth, J. D. Kilburn, P. N. Bartlett, Chem. Eur. J. 2014, 20, 5550-5554.

[16] aB. Barbier, J. Pinson, G. Desarmot, M. Sanchez, J. Electrochem. Soc. 1990, 137, 1757-1764; bA. J. Downard, Electroanal. 2000, 12, 1085-1096.

[17] aM. A. Ghanem, J.-M. Chrétien, A. Pinczewska, J. D. Kilburn, P. N. Bartlett, J. Mater. Chem. 2008, 18, 4917-4927; bM. A. Ghanem, I. Kocak, A. Al-Mayouf, M. Alhoshan, P. N. Bartlett, Electrochim. Acta 2012, 68, 74-80.

[18] aM. A. Ghanem, J.-M. Chrétien, J. D. Kilburn, P. N. Bartlett, Bioelectrochem. 2009, 76, 115125; bA. Pinczewska, M. Sosna, S. Bloodworth, J. D. Kilburn, P. N. Bartlett, J. Am. Chem. Soc. 2012, 134, 18022-18033.

[19] G. Henriksson, G. Johansson, G. Pettersson, J. Biotechnol. 2000, 78, 93-113.

[20] R. Ludwig, R. Ortiz, C. Schuyz, W. Harreither, C. Sygmund, L. Gorton, Anal. Bioanal. Chem. 2013, 405, 3637-3658.

[21] R. Ludwig, W. Harreither, F. Tasca, L. Gorton, ChemPhysChem 2010, 11, 2674-2697.

[22] T.-C. Tan, D. Kracher, R. Gandini, C. Sygmund, R. Kittl, D. Haltrich, B. M. Hällberg, R. Ludwig, C. Divne, Nature Commun. 2015, 6, Art. No. 7542.

[23] P. Kielb, M. Sezer, S. Katz, F. Lopez, C. Schulz, L. Gorton, R. Ludwig, U. Wollenberger, I. Zbger, I. M. Weidinger, ChemPhysChem 2015, 16, 1960-1968.

[24] J. D. Gregory, J. Am. Chem. Soc 1955, 77 (14), 3922-3923.

[25] G. R. Grimsley, J. M. Scholtz, C. N. Pace, Protein Sci. 2009, 18, 247-251.

[26] S. S. Wong, E. Joseievich, A. T. Woolley, C. L. Cheung, C. M. Lieber, Nat Commun. 1998, 394, 52-56.

[27] A. Flitsch, E. N. Prasetyo, C. Sygmund, R. Ludwig, G. S. Nyanhongo, G. M. Guebitz, Enzyme Microb. Technol. 2013, 52, 60-67.

[28] C. Sygmund, P. Santner, I. Krondorfer, C. K. Peterbauer, M. Alcalde, G. S. Nyanhongo, G. M. Guebitz, R. Ludwig, Microb Cell Fact 2013, 12.

[29] C. Sygmund, P. Staudigl, M. Klausberger, N. Pinotsis, K. Djinovic-Carugo, L. Gorton, D. Haltrich, R. Ludwig, Microb Cell Fact 2011, 10. 
[30] W. Harreither, A. K. G. Felice, R. Paukner, L. Gorton, R. Ludwig, C. Sygmund, Biotechnology Journal 2012, 7. 